\title{
Application of Bokashi Fertilizer and Duration of Water Supply to Increase Growth, Yields, and Quality of Shallot in Dryland
}

\author{
Muhammad Ansar ${ }^{1 *}$, Bahrudin ${ }^{1}$, Saiful Darman ${ }^{1}$, Paiman $^{2}$ \\ ${ }^{1}$ Faculty of Agriculture, Tadulako University, City of Palu 94118, Indonesia \\ ${ }^{2}$ Faculty of Agriculture, Universitas PGRI Yogyakarta, City of Yogyakarta 55182, Indonesia
}

Corresponding Author Email: apasigai@untad.ac.id

https://doi.org/10.18280/ijdne.150513

Received: 27 May 2020

Accepted: 19 September 2020

\section{Keywords:}

shallot, organic fertilizer bokashi, watering, dryland

\begin{abstract}
This study aims to improve the growth, yield, and quality of LP-VoS bulbs by applying bokashi fertilizer from goat manure and regulating the duration of water supply with a sprinkler irrigation system. This research is a field that arranged in split-plot design. The main plot is the duration of irrigation water supply, consisting of three levels, $0.5 ; 1,0$; and 1.5 hours. The subplot is giving organic fertilizer bokashi goat manure, which consists of two kinds, namely: without bokashi fertilizer and the addition of bokashi

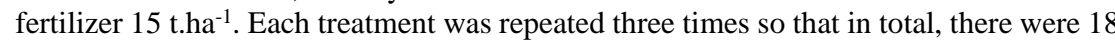
experimental plot units. The results showed that the duration of irrigation 0.5 hours at intervals of 3 days, followed by the application of 15 t.ha $^{-1}$ bokashi organic fertilizer could increase the bulb circle of 'Lembah Palu' varieties. The use of bokashi organic fertilizer 15 t.ha $^{-1}$ could increase soil moisture so it can growth, yields, and quality of shallot bulb. The duration of irrigation with a sprinkler system for 0.5-1.0 hours at intervals of 3 days could result in the growth of total dry weight and total leaf area per plant as well as the number of tubers per clump, fresh weight of tubers per clump and yield of tubers per hectare higher than treatment of water for 1.5 hours at intervals of 3 days. Water supply regulations and the use of bokashi organic fertilizers can increase the growth, yield, and quality of LP-VoS bulbs on dryland. For the cultivation of 'Lembah Palu' varieties of shallots in dry land, it is necessary to apply organic fertilizers to increase the soil water content for increased production and quality.
\end{abstract}

\section{INTRODUCTION}

In Central Sulawesi Province, there are local varieties of shallots that have been released by the government as superior national varieties. The shallots are known as the 'Lembah Palu' variety. This type of shallot is the best raw material for the fried onion industry because it has a distinctive aroma, dense texture, savory taste, and is resistant in storage after frying, which cannot be found in other types of fried onions. Shallots of this variety are not found in other areas, whereas in Central Sulawesi, only developed by farmers in the Palu Valley region, which covers the whole area of Palu City, as well as parts of the Donggala and Sigi Regencies. The LP-VoS can adapt well at altitudes less than $400 \mathrm{~m}$ above sea level (ASL). According to Bahrudin et al. [1], Shallot 'Lembah Palu' variety is the primary raw material for the fried onion industry in Central Sulawesi.

The productivity of LP-VoS at the farm level is still low, ranging only between 3-4 t.ha ${ }^{-1}$, while the potential yield can reach 9.7 t.ha $^{-1}$. The LP-VoS is generally cultivated in dryland so that the main limiting factor in increasing LP-VoS productivity in production centers in Central Sulawesi is the availability of water and low soil organic matter content. Besides, cultivation technology used by farmers in general still uses inorganic fertilizers, while their use is still lacking. The continuous application of inorganic fertilizers results in decreased physical and chemical conditions of the soil, especially soil fertility. Fertilization of onion plants can be used inorganic and organic fertilizer. The use of inorganic fertilizers without the addition of organic fertilizers over a long period causes a decrease in the physical and chemical capabilities of the soil, so the application of solid and liquid organic fertilizers is predicted to be more effective because the elements are more than one [2].

Generally, shallots are cultivated on irrigated paddy fields with the Surjan system, where irrigation water is supplied to the ditch/gutter between beds by inundating the beds for a long time. Still, the LP-VoS generally cultivated on dry land using different of directions and beds forms, namely, some use high beds and deep beds and beds in the course of the slope of the land or beds in the direction of cutting the slope of the land. LP-VoS planted on dry land with different classes and forms of seedbeds. The path of the bed, as well as its interaction with the structure of the bed. It did not significantly affect the growth and yield of shallots 'Lembah Palu' on dry land.

The use of a sprinkler irrigation system is more efficient compared to a puddle irrigation system. However, it is not known exactly how long the sprinkler must run or the amount of water volume that must be given according to LP-VoS needs. The use of organic material from Bokashi Goat fertilizer is expected to increase the soil water content. Organic matter has a high ability to bind and store water. Providing organic material can increase soil fertility and the availability of nutrients needed by plants. The application of organic 
fertilizer is considered as an effective way to maintain soil fertility and plant growth [3].

In some locations of LP-VoS production centers on dry land, productivity is very low due to irrigation water that is not precisely suited to the needs of LP-VoS plants during its growing period. According to Sumbayak \& Susila [4], water consumption of conventional onion plants that are planted is $500 \mathrm{~m}^{-3} \cdot \mathrm{ha}^{-1}$. Therefore, it is essential to develop an onion planting system that can improve the efficient use of water and yields.

Efforts to save water use in shallots cultivation on dry land need to be a concern because the level of water availability for irrigation is minimal. One way to improve the efficiency of water use is to set an appropriate time interval for irrigation and the use of organic material. It can function to bind water in the soil so that the amount of irrigation water used for shallot cultivation in dry land becomes more efficient, and the productivity of shallot plants becomes higher. At the research location, which is one of the LP-VoS production centers in the Palu Valley region, the source of irrigation water uses a piped irrigation system, and its use is regulated at intervals of only three days. For this reason, it is essential to manage the time and time for sufficient water supply to support the growth and yield of shallots. Irrigation scheduling is necessary for irrigation water management [5].

Onion roots are fasciculate, slightly ramified, short, and generally do not exceed a depth of $0.20-0.25 \mathrm{~m}$ in soil. Due to this shallow root system, onions are susceptible to water stress [6]. Excess and lack of water cause water stress, thus affecting the physiological activities, growth, and yield of tubers significantly, different for each variety and altitude. Therefore, frequent and adequate irrigation management is required to achieve good yield [7].

The addition of organic fertilizer can increase soil organic matter content. Many reports state that applying organic fertilizers can result in increased water holding capacity, porosity, infiltration capacity, hydraulic conductivity, and stable aggregation of water, as well as a decrease in bulk density and surface hardening. Giving lime, fertilizer, and manure on the status of soil organic matter and soil physical properties is very important for agricultural sustainability [8]. Giving organic fertilizer into the soil is one way to manage soil nutrients to increase crop production sustainably. Organic matter has an essential role in improving the physical properties of the land, especially the ability of the soil to bind water, as well as the chemical properties of the land associated with improving nutritional status and plant availability. Increased crop productivity can be done through integrated nutrient management (INM). The INM system is more efficient using compost, agricultural waste, green manure, wastewater, mud, and others [9].

The application of organic fertilizer can minimize the use of inorganic fertilizers in crop cultivation. Several types of manure affect the quality of bokashi, including the content of nutrients $\mathrm{P}$ and $\mathrm{K}$. At the same time, showing the color, odor, and texture is not different from the color, odor, and texture material. All types of manure do not have to affect the $\mathrm{N}$ and $\mathrm{C} / \mathrm{N}$ content of the bokashi ratio [10]. Goat manure droppings have higher $\mathrm{pH}$ and $\mathrm{EC}$ values than cow and poultry manure, both in fresh and compost samples. A significant increase in EC values was observed in compost, while the $\mathrm{pH}$ can be reduced by composting [11]. Organic farming has the potential to have a significant contribution to the global food supply, accompanied by a reduction in the detrimental environmental impacts of conventional agriculture [12].

This study aims to improve the growth, yield, and quality of LP-VoS bulbs by applying bokashi fertilizer from goat manure and regulating the duration of water supply with a sprinkler irrigation system.

\section{MATERIAL AND METHOD}

\subsection{The study area}

This research was conducted in June-November 2015, on the farmer's land in Sidera Village, Sigi-Biromaru Regency, Sigi Regency, Central Sulawesi Province. The study was conducted on dryland located in the lowlands with an altitude of $120 \mathrm{~m}$ ASL. Daily temperatures recorded an average of 29$30^{\circ} \mathrm{C}$, and soil humidity $60-65 \%$. Shallots of the variety 'Lembah Palu' grow well at an altitude of $\leq 400 \mathrm{~m}$ ASL, but the center of the development is generally at an altitude of 50$250 \mathrm{~m}$ ASL. Analysis of soil, organic fertilizer, and plants were carried out at the Soil Science Laboratory, Faculty of Agriculture, Tadulako University, Palu.

\subsection{Experiment design}

This research was used split plot design with three replications. The main plot is the duration of irrigation water using a sprinkler, consisting of giving water for 0.5 hours every three days, giving water for 1.0 hours every three days, and giving water for 1.5 hours every three days. Sub-plot is the application of organic fertilizer (goat manure bokashi), consisting of without organic fertilizer, and providing organic fertilizer bokashi with a dose of 15 t.ha $^{-1}$ or equivalent to 7.4 $\mathrm{kg} / \mathrm{plot}$. Thus, in total, there are 18 test plots.

\subsection{Research procedures}

The plot size is $105 \mathrm{~cm}$ (wide) x $255 \mathrm{~cm}$ (long) x $25 \mathrm{~cm}$ (high). The distance between the main plots (treatment of sprinkling irrigation water) is $2.5 \mathrm{~m}$ (according to the radius of water reach from the sprinkle). At the same time, the distance between Sub Plots (treatment of organic fertilizer) is $50 \mathrm{~cm}$, which also functions as drainage water channels. The spacing of shallot is $15 \mathrm{~cm} \mathrm{x} 15 \mathrm{~cm}$, and in each hole is planted with one bulb of shallot seeds or each trial plot, there are 119 populations of shallot plants per plot.

The shallot seeds used are of medium size and have been stored for 1.5 months after harvest. The use of medium size bulbs in the onion production system can reduce production costs by $33-40 \%$ without reducing the level of productivity [13]. Medium bulb size was appropriately applied in shallots cultivation due to reducing the production cost down to 33$40 \%$ [13]. Before planting, the seeds are sterilized by soaking the seeds with a fungicide solution (Dithane M-45) of $20 \mathrm{~g}$ per $\mathrm{kg}$ of seeds for 30 minutes. Shallot seeds are planted $3-5 \mathrm{~cm}$ deep.

In each trial, the plot was used silver black plastic mulch. It was installed a week before planting, to reduce weed growth. In black silver plastic mulch, a hole is placed in the planting of tubers with a diameter of $12 \mathrm{~cm}$ with spacing by the spacing of $15 \mathrm{~cm} \times 15 \mathrm{~cm}$.

The installation of irrigation water is by connecting a 1 "PVC pipe as the main network, then connecting it with a plastic hose with a diameter of $3 / 4$ " to the PVC pipe, which is a 
piped irrigation water pipeline from the water reservoir. Sprinkler system irrigation is run using a water pump merk DAB Semi Jet type Jet $123 \mathrm{M}$ as a driving force to run the water and the sprinkler. Furthermore, the application of irrigation water with a sprinkler is adjusted in the duration of watering time in each main plot.

Irrigation water application with sprinkles for 0.5 hours is equivalent to $184.1 \mathrm{~mm}$; giving water for 1.0 hour is equal to $331.8 \mathrm{~mm}$, and the form of water for 1.5 hours is equivalent to $517.3 \mathrm{~mm}$ of water at intervals of three days each. The use of irrigation water is carried out evenly in all trial plots for a week at the beginning of planting to spur the growth of shallot bulbs. Furthermore, the application of water is carried out following the treatment of each time the water is applicated in the main plot. The application of water is stopped at the time of the week before harvest. The soil and tubers of the shallots become dry at harvest.

Organic fertilizer (bokashi goat manure) was applied two weeks before planting by sprinkling and mixing with the soil evenly on each trial plot that was treated with organic compost. The dose of organic fertilizer given is $15 \mathrm{t}^{\mathrm{h}} \mathrm{ha}^{-1}$, equivalent to $7.4 \mathrm{~kg} \cdot \mathrm{plot}^{-1}$. Inorganic fertilizers are given according to recommendations for shallot cultivation, namely $100 \mathrm{~kg}$ urea, $200 \mathrm{~kg} \mathrm{ZA}, 200 \mathrm{~kg} \cdot \mathrm{ha}^{-1} \mathrm{SP}-36$, and $150 \mathrm{~kg} \cdot \mathrm{ha}^{-1} \mathrm{KCl}$. The application of SP-36 and $\mathrm{KCl}$ fertilizers is only made once at the beginning of planting. In contrast, urea and ZA fertilizers are given two stages, namely at 7 (seven) days after planting (DAP) and when the plants are 30 DAP, each half recommended dosage (50 kg.ha- ${ }^{-1}$ urea and $\left.100 \mathrm{~kg} \cdot \mathrm{ha}^{-1} \mathrm{ZA}\right)$. Inorganic fertilizers are given by an array of about $5 \mathrm{~cm}$ beside the shallots plant.

Plant maintenance includes cleaning weeds and controlling pests and diseases. Weed cleansing is done manually by pulling weeds that grow in the planting holes and ditches between the test plots. Pest control is done, both mechanically and chemically. Mechanical power by taking pests on plants and then killing them. Chemical pest control using pesticides. Leaf caterpillar pests are controlled using an insecticide made from active chlorpyrifos concentration of $1 \mathrm{ml}^{-1 i t e r}{ }^{-1}$ water. The fungus in shallot plants was controlled using Mankozeb $80 \%$ fungicide concentration 3 g.liter ${ }^{-1}$ water. For pesticides and fungicides to adhere well to the leaves of shallot plants bio soft concentrations of $1 \mathrm{ml}^{-1 i t e r^{-1}}$ of water are used. Shallot bulbs are harvested after 70 (DAP).

\subsection{Parameter}

Observations were done on the components of the soil environment, namely soil water content, and soil temperature. Growth components were observed, including total dry weight per plant and total leaf area per plant at the age of 20,30,40, and 50 DAP. Destructive observations were carried out in 3 clumps as sample plants in each experimental plot. Components of shallot yield and quality of shallot tubers observed included: number of tubers per clump, fresh weight of tubers per clump, fresh tuber weight per hectare, total soluble solids, and water content of tubers and tuber wrap.

Soil sampling for water content observations was carried out in the afternoon for 4 consecutive days. The representation of soil temperature is observed periodically for ten days, namely at the age of 10-19 DAP and observation is carried out at $07.00,09.00,11.00,13.00,15.00$, and 17.00 Central Indonesia Time (CIT). The yield components (the weight of fresh shallot tubers per hectare) were taken from 40 sample plants in a $1.0 \mathrm{~m}^{2}$ tile in each trial plot. The yield of tubers per hectare is calculated using the formula follows. Tuber yield $\left(\right.$ t.ha $\left.{ }^{-1}\right)=8,000 \mathrm{~m}^{2} /$ area of tile $\left(\mathrm{m}^{2}\right) \mathrm{x}$ tuber weight per tile plot.

\subsection{Statistical analysis}

The data were analyzed using analysis of variance (ANOVA) at a P-value of 0.05 [14]. To find out, the differences between treatments were using the Tukey test at a $\mathrm{P}$-value of 0.05 .

\section{RESULT AND DISCUSSIONS}

\subsection{Soil characteristics and organic fertilizers}

Based on the results of the initial soil analysis at the study site, the soil permeability value was $1.64 \mathrm{~cm} /$ hour, and bulk density was $1.58 \mathrm{~g} / \mathrm{cm}^{3}$, porosity was $40.40 \%$. The results of the analysis of organic fertilizer (goat manure bokashi) obtained C-organic content of $36.33 \%$ (very high), $\mathrm{N}$ of $0.39 \%$ (moderate), $\mathrm{P}$ of $0.24 \%$ (moderate) and $\mathrm{K}$ of $1.65 \%$ (very high). Denser soils have greater bulk density than mineral soils with upper bulk content lower than the land below. Sandy soil and sandy loam generally have fill weights ranging from 1.3-1.8 g $\mathrm{cm}^{-3}$, while more excellent grounds range typically in weight between $1.0-1.3 \mathrm{~g} \mathrm{~cm}^{-3}$.

Organic matter causes soil with less fill weight because it can increase soil porosity and permeability. Increased organic matter content causes increased water retention in sandy soils and decreased fine-textured soil. All soils show an increase in water retention, and the most significant increase is in sandy and muddy soils [15]. Soil organic matter greatly determines the interaction between abiotic and biotic components in soil ecosystems. The C-organic content in the soil must be maintained at a level of not less than two percent. The addition of soil organic matter during tillage aims to ensure that the content of organic matter in the soil does not decrease over time because of the mineralization decomposition process. Mineral fertilizers can increase soil porosity by increasing regular and irregular pores [16].

\subsection{Soil water content}

There was no significant effect of the interaction of the combination of the treatment of irrigation water duration and bokashi organic fertilizer on soil water content on the first to fourth-day observations. The duration of irrigation water and organic bokashi fertilizer did not significantly affect the soil water content on the first and second-day observations but had a significant effect on the third and fourth-day observations. The results of the Tukey test at P-value 0.05 showed that the soil water content on the third day, giving water for 1.5 hours, produced the highest soil water content (14.86\%) and significantly different from other treatments. The lowest soil water content $(12.17 \%$ ) was in the water supply for 0.5 hours, but it was not significance different from the water supply of 1.0 hour. Furthermore, on the fourth-day observation, all treatments showed a decrease in soil water content. However, the treatment of 1.5 hours of water still showed a higher soil water content $(12.46 \%)$ and significantly different from the treatment of 0.5 hours of water, but not significant different from the treatment of giving water 1.0 hour. Irrigation water 1.5 hours showed the highest soil water content; this is due to 
the texture of the middle to fine entisol, which has a large surface area and volume of pore space so that it can bind water to the maximum. Fine-textured soil has a maximum total water-binding capacity, but the maximum available water is bound to medium-textured soil. The addition of water volume will increase soil improvement and improve environmental conditions to achieve optimal conditions so that soil water content is maintained. The amount of water given to plants is very influential on soil moisture. The application of water in a particular volume of planting media is shown to maintain and increase soil moisture until it reaches its optimum.

The addition of organic matter will increase the ability of the soil to retain water so that the ability to provide soil water for plant growth increases. The presence of organic matter in sandy soils will increase water content in the field capacity, as a result of the growth of medium-sized pores and a decrease in macropores. Increased water retention capacity will have an impact on increasing the availability of water for plant growth. The addition of organic fertilizer can improve the physical and biological properties of the soil. There is an increase in macropores ranging from $50-500 \mu \mathrm{m}$ in soil treated with organic fertilizer, mainly due to a rise in elongated pores. It is considered very important both in the soil-water-plant relationship and maintaining a good soil structure [16].

Figure 1 showed that giving water for 1.5 hours resulted in a higher soil moisture content than giving water from 0.5 to 1.0 hours until the $4^{\text {th }}$ day of observation, and Figure 2 showed that the application of organic fertilizer $15 \mathrm{t} / \mathrm{ha}$ resulted in a higher soil moisture content than without organic fertilizer, until the $4^{\text {th }}$ day of observation.

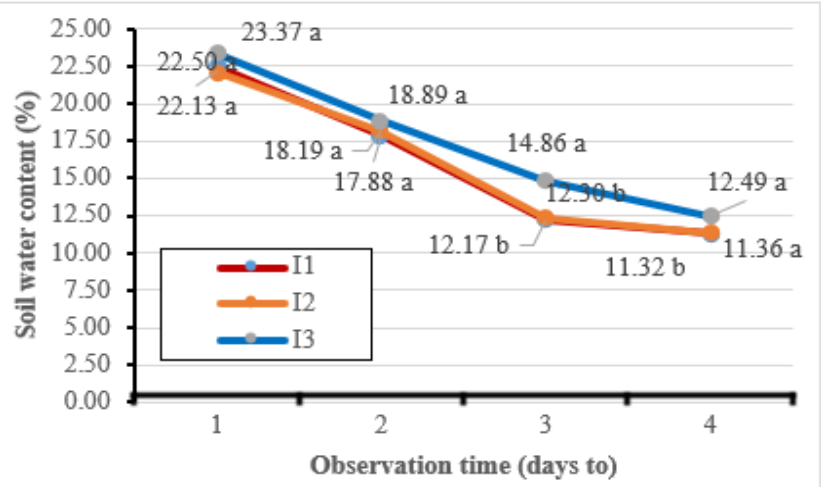

Figure 1. Condition of soil water content with the duration of water treatment on the first day until the fourth day

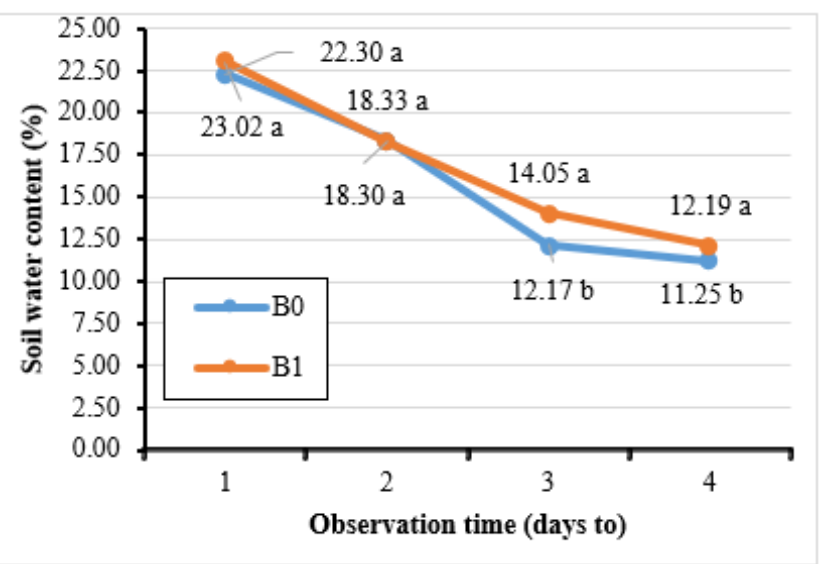

Figure 2. Condition of soil water content with the treatment of organic fertilizer on the first day to the fourth day

\subsection{Soil temperature}

There was no significant effect of the interaction of the combination of the treatment duration of irrigation water and organic bokashi fertilizer on soil temperature at each observation time. Patterns of average soil temperature changes from comments periodically for ten consecutive days conducted at 07.00, 09.00, 11.00, 13.00, 15.00 and 17.00 CIT, as shown in Figure 3 and 4.

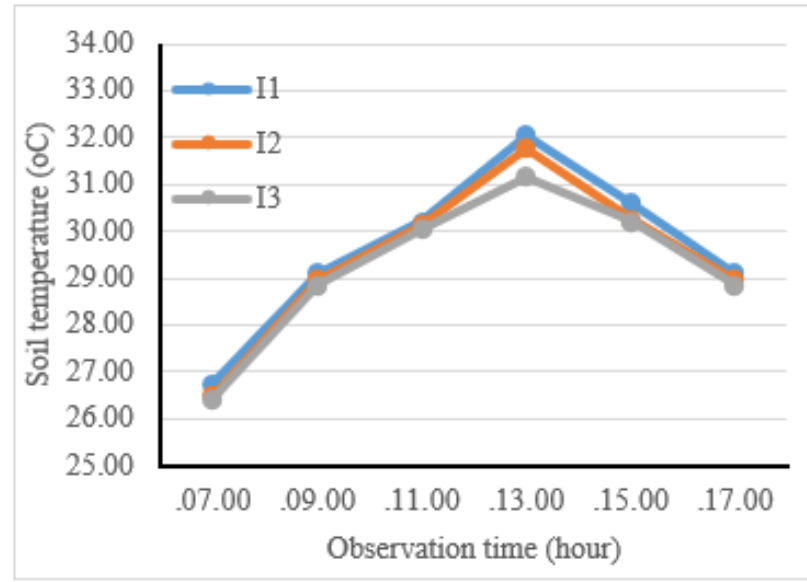

Figure 3. Average soil temperature at each time of observation in the lengthy treatment time of giving water

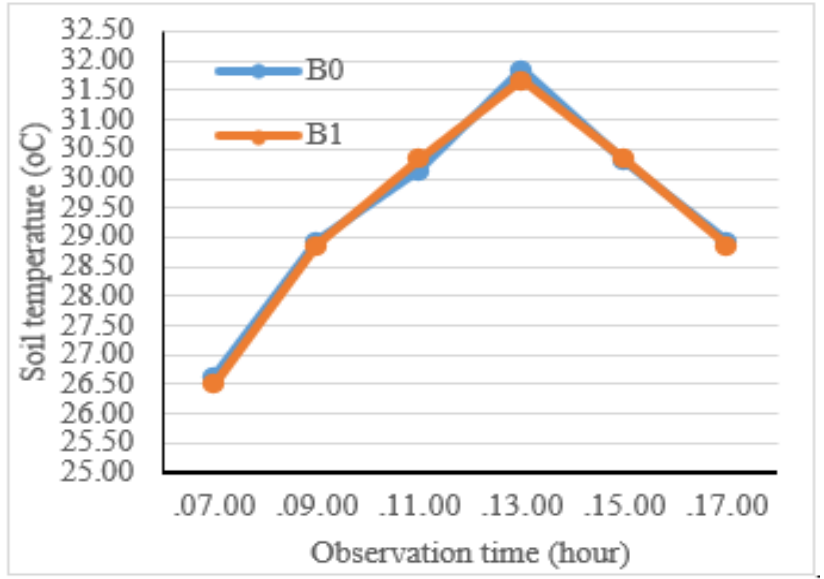

Figure 4. Average soil temperature at each time of observation in the treatment of organic bokashi fertilizer

Figure 3 shows the pattern of changes in soil temperature from each observation time. Higher soil temperature $\left(32.0^{\circ} \mathrm{C}\right)$ in the treatment of irrigation duration for 0.5 hours occurred at 13.00 CIT, compared to other treatments until 17.00 CIT. Instead, the soil temperature is lower $\left(26.4^{\circ} \mathrm{C}\right)$ in the treatment of water for 1.5 hours at 13.00 CIT. It shows that soil temperature is influenced by soil water content based on the duration of irrigation, although this study did not provide significant results. In Figure 4, it is shown that the treatment of bokashi fertilizer and without bokashi fertilizer results in changes in soil temperature with almost the same pattern during observation. The highest soil temperature was obtained in the treatment without organic fertilizer bokashi $\left(31.8^{\circ} \mathrm{C}\right)$ at $13.00 \mathrm{CIT}$, and the lowest soil temperature was obtained in the treatment of bokashi fertilizer at a dose of 15 t.ha $^{-1}\left(26.5^{\circ} \mathrm{C}\right)$ at 07.00 CIT. Bokashi can improve soil aeration and soil pore space so that the temperature in the soil is maintained. 
Irrigation water duration has a very significant effect on decreasing air temperature, increasing soil and air humidity, increasing plant height and widening the leaf area of chili plants [17]. Alluvial soils have low levels of organic matter and total $\mathrm{N}$, so the use of organic fertilizers and adequate biological fertilizers is expected to improve the physical and chemical properties of the soil and can increase the yield of shallots [18].

\subsection{Total dry weight per plant}

There was no significant interaction between the combination of irrigation water duration treatment and organic bokashi fertilizer on the total dry weight per plant. Still, the treatment of water and organic fertilizer each gave a significant effect on the total dry weight per shallot plant. Tukey test results at P-value 0.05 (Table 1) show that the addition of 15 t.ha $^{-1}$ bokashi organic fertilizer produced a higher total dry weight per shallot plant at the age of 20,30, 40 , and 50 DAP and was significantly different from without organic fertilizer. Organic fertilizer, in addition to improving the physical properties of the soil, also contains nutrients, especially the element $\mathrm{K}$, which is needed in the process of plant growth. Bokashi from goat manure has the highest $\mathrm{K}$ from the other bokashi [10]. The application of goat manure has a significant effect on the number of leaves and fresh weight of your plants, where a dose of 1:4 can increase the fresh weight of plants, and treatment of 1:2 can increase the number of plants leaves [19].

Furthermore, the duration of irrigation water treatment significantly affected the total dry weight per shallot plant at the age of 20,30,40, and 50 DAP, based on the results of the Tukey test at P-value 0.05 (Table 1). It was found that the duration of irrigation water was 0.5 hours produces the highest total dry weight per plant and is significantly different from the treatment of 1.5 hours water, but not substantially different from the water supply of 1.0 hours. The availability of water largely determines plant growth in the form of dry plant production because it is the main ingredient in the photosynthesis process, which will produce plant dry matter.

Table 1. The effect of organic matter and duration of irrigation water on the total dry weight of shallot at age 20 , 30,40 and 50 DAP

\begin{tabular}{ccccc}
\hline \multirow{2}{*}{ Treatment } & \multicolumn{5}{c}{ Plant age (DAP) } \\
\cline { 2 - 5 } & 20 & 30 & 40 & 50 \\
\hline $\begin{array}{c}\text { Bokashi Fertilizers } \\
\left(\text { t.ha }^{-1}\right) \\
0\end{array}$ & & & & \\
15 & $0.86 \mathrm{~b}$ & $1.86 \mathrm{~b}$ & $3.26 \mathrm{~b}$ & $5.54 \mathrm{~b}$ \\
$1.11 \mathrm{a}$ & $2.47 \mathrm{a}$ & $4.10 \mathrm{a}$ & $7.13 \mathrm{a}$ \\
\hline $\begin{array}{c}\text { Tukey test P-value } \\
0.05\end{array}$ & 0.11 & 0.43 & 0.42 & 1.16 \\
\hline $\begin{array}{c}\text { Duration of Irrigation } \\
\text { (hours) }\end{array}$ & & & & \\
0.5 & $1.03 \mathrm{a}$ & $2.48 \mathrm{a}$ & $4.13 \mathrm{a}$ & $7.24 \mathrm{a}$ \\
1.0 & $1.09 \mathrm{a}$ & $2.41 \mathrm{a}$ & $3.74 \mathrm{ab}$ & $6.92 \mathrm{a}$ \\
1.5 & $0.83 \mathrm{~b}$ & $1.60 \mathrm{~b}$ & $3.16 \mathrm{~b}$ & $4.85 \mathrm{~b}$ \\
\hline $\begin{array}{c}\text { Tukey test P-value } \\
0.05\end{array}$ & 0.16 & 0.67 & 0.65 & 1.78 \\
\hline $\begin{array}{c}\text { Interaction between } \\
\text { treatments }\end{array}$ & $(-)$ & $(-)$ & $(-)$ & $(-)$ \\
\hline
\end{tabular}

Note: Numbers followed by the same letter in the column, and the same treatment are not significantly different based on the Tukey test P-value 0.05 (-) there is no interaction between organic matter treatment and the duration of irrigation water supply.
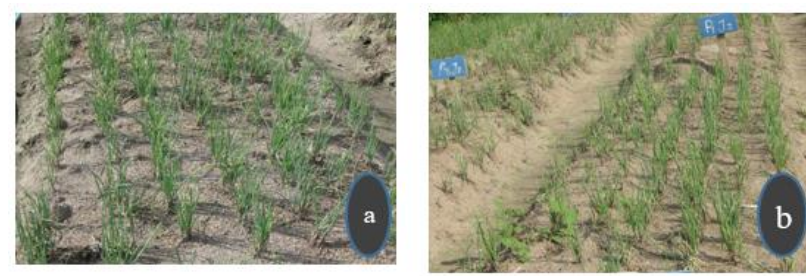

Figure 5. (a, b) 'Lembah Palu' varieties of shallot manual without treatment by farmer
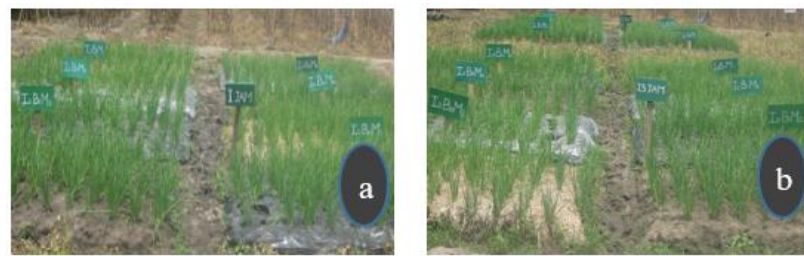

Figure 6. $(\mathrm{a}, \mathrm{b})$ 'Lembah Palu' varieties of shallot with treatment of irrigation and organic fertilizers

Figure $5(\mathrm{a}, \mathrm{b})$ shows that the growth of shallot on the 'Lembah Palu' variety is not good, without the application of irrigation water and the addition of organic fertilizers. On the other hand, Figure $6(\mathrm{a}, \mathrm{b})$ shows the better growth of shallot on the 'Lembah Palu' variety with the treatment of water irrigation and the addition of organic fertilizers.

Water is the raw material for the process of photosynthesis, solvents and biochemical reactions, and transporting medium compounds. Water provides cell turgor for cell division and enlargement while keeping plant temperatures constant. At the beginning of plant growth, water requirements are low because the size of the habitus is still small so that the surface area of plants that carry out evapotranspiration is little. Water requirements for plants are highest in periods of maximum vegetative growth [20]. Lack of water can affect cell turgor, which will reduce cell development, protein synthesis, and cell wall synthesis, so that plant growth is inhibited. The initial influence of plants that lack water is the occurrence of obstacles to the opening of the leaf stomata, which then have a significant effect on physiological and metabolic processes in plants [21]. The impact of water availability on plant growth depends on the level of water availability experienced and the type or cultivar planted. In soybean plants, the interval of water administration also significantly affects the parameters of plant height, some leaves, wet plant weight, total dry weight per plant, damp pod weight, and pod dry weight as well as on plant growth and yield [22].

\subsection{Total leaf area per plant}

There was no significant interaction between the combination of irrigation water duration treatment and organic bokashi fertilizer on the total leaf area per plant. Still, the single factor of treatment of time irrigation water and organic fertilizer respectively had a considerable effect on the total leaf area per shallot, except at the age of 20 DAP had no significant impact. Tukey test results at P-value of 0.05 (Table 2) show that the application of $15 \mathrm{t}^{-\mathrm{ha}^{-1}}$ bokashi organic fertilizer produced a higher total leaf area per shallot at 30,40 , and 50 DAP and was significantly different from without organic fertilizer. Furthermore, the length of water treatment significantly affected the total leaf area per shallot plant at the age of 30,40 , and 50 DAP. 
Table 2. Effect of organic matter and irrigation time on the total leaf area $\left(\mathrm{cm}^{2}\right.$.plant $\left.{ }^{-1}\right)$ of shallots at the age of $20,30,40$ and 50 DAP

\begin{tabular}{|c|c|c|c|c|}
\hline \multirow{2}{*}{ Treatment } & \multicolumn{4}{|c|}{ Plant age (DAP) } \\
\hline & 20 & 30 & 40 & 50 \\
\hline \multicolumn{5}{|l|}{$\begin{array}{c}\text { Bokashi } \\
\text { Fertilizers } \\
\left(\text { t.ha }^{-1}\right)\end{array}$} \\
\hline 0 & 192.63 & $722.42 \mathrm{~b}$ & $1,174.21 \mathrm{~b}$ & $2,309.70 \mathrm{~b}$ \\
\hline 15 & 185.20 & $889.00 \mathrm{a}$ & $1,457.41 \mathrm{a}$ & $2,619.5 \mathrm{~b} \mathrm{a}$ \\
\hline $\begin{array}{c}\text { Tukey test } \\
\text { P-value } 0.05\end{array}$ & Ns & 107.78 & 210.03 & 248.58 \\
\hline \multicolumn{5}{|l|}{$\begin{array}{l}\text { Duration of } \\
\text { Irrigation } \\
\text { (hours) }\end{array}$} \\
\hline 0.5 & 207.61 & $965.09 \mathrm{a}$ & $1,446.10 \mathrm{a}$ & $2,937.20 \mathrm{a}$ \\
\hline 1.0 & 186.36 & $929.66 \mathrm{a}$ & $1,415.10 \mathrm{a}$ & $2,466.70 \mathrm{~b}$ \\
\hline 1.5 & 172.78 & $522.38 \mathrm{~b}$ & $1,086.20 \mathrm{~b}$ & $1,989.90 \mathrm{c}$ \\
\hline $\begin{array}{c}\text { Tukey test } \\
\text { P-value } 0.05 \\
\end{array}$ & Ns & 165.51 & 322.55 & 381.75 \\
\hline $\begin{array}{l}\text { Interaction } \\
\text { between } \\
\text { treatments }\end{array}$ & $(-)$ & $(-)$ & $(-)$ & $(-)$ \\
\hline
\end{tabular}

Note: Numbers followed by the same letter in the column, and the same treatment are not significantly different based on the Tukey test P-value 0.05 . (-) there is no interaction between organic matter treatment and the duration of irrigation water supply.

Based on Table 2, the duration of a 0.5 -hour water supply produces the highest total leaf area per plant, different from 1.5-hour water treatment. Irrigation duration of 0.5 hours and 1.0-hour water supply did not significance different at the age of 30 and 40 DAP. At the age of 50 DAP between treatments, the duration of irrigation showed significantly different. The length of time given to water affects the growth of the number of plant leaves. The amount of water that can cause a lot of water saturation and inhibit the process of plant growth. An essential condition for the plant growth process is the soil in the field of field capacity. Field capacity is the amount of water left in the soil after all the gravitational water has been drained. Plants that get low or excess water supply for a long time will experience water pressure and affect the physiological processes of the plant [22]. Effect of water pressure on plant morphology, production level, and marketable yield. The reduction in yield due to water pressure can be caused by reduced leaf area and reduced photosynthesis per unit leaf area [23]. The interval of water application in different sweet potato plants affected the length of the tendrils at the age of 60 and
90 DAP, and the leaf area and tuber weight were considerable [24].

\subsection{Number of tubers per clump}

There was no significant effect of interaction between the combination of irrigation water duration treatment and bokashi organic fertilizer on the number of tubers per clump. However, the treatment of irrigation duration and addition of bokashi organic fertilizer each gave a significant influence on the number of tubers per clump. The results of the Tukey test at Pvalue 0.05 (Table 3 ) indicate that the application of $15 \mathrm{t}^{\mathrm{tha}} \mathrm{h}^{-1}$ organic fertilizer produces more tubers per clump (10.46 tubers) and is significantly different from without the application of organic bokashi fertilizer (8.26 tubers).

The application of organic fertilizer has a role in inhibiting the washing of nutrients around the roots, in increasing the nutrient content around the roots as supporting the formation of saplings and tubers in onions. Organic fertilizers can increase nutrient reserves in the plant rooting zone and reduce nutrient leaching, thereby increasing crop production in acidic and weathered tropical soils [25]. The duration of water treatment significantly affected the number of tubers per clump. The duration of a 0.5 -hour water supply resulted in a higher number of tubers per clump. It was different from the 1.5-hour water supply, but not different from the 1.0 hour. It shows that different amounts of water affect the formation of the number of onion tubers. A higher amount of water does not guarantee the establishment of a large number of tubers. It is because of onions, including plants that do not need water in large quantities. The LP-VoS is better adapted to the dry land environment by providing water that is suitable for the needs during its growth period.

\subsection{Fresh weight of tubers}

There was no significant effect of interaction between the combination of irrigation water duration treatment and bokashi organic fertilizer on the number of fresh weight of tubers per clump. But the treatment duration of irrigation water and giving organic fertilizer bokashi each had a significant influence on the fresh weight of tubers per clump. The results of the Tukey test at P-value 0.05 (Table 3) indicate that the application of 15 t.ha ${ }^{-1}$ bokashi organic fertilizer produces more fresh tuber weight per clump (10.46 tubers) and is significantly different from without organic fertilizer $(8.26$ tubers).

Table 3. Effect of bokashi organic fertilizers and duration of irrigation on the number of tubers, tuber fresh weight, yield of tubers per hectare, total soluble solids and shallot tuber moisture content

\begin{tabular}{|c|c|c|c|c|c|}
\hline Treatment & $\begin{array}{c}\text { The tuber number per } \\
\text { clump }\end{array}$ & $\begin{array}{c}\text { Tuber fresh weight } \\
\left.\text { (g.clump }{ }^{-1}\right)\end{array}$ & 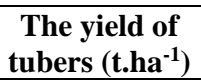 & $\begin{array}{l}\text { Total soluble } \\
\text { solids (Brix) }\end{array}$ & $\begin{array}{c}\text { Tuber moisture } \\
\text { content }(\%)\end{array}$ \\
\hline \multicolumn{6}{|l|}{ Bokashi Fertilizers (t.ha $\left.{ }^{-1}\right)$} \\
\hline 0 & $8.26 \mathrm{~b}$ & $29.32 \mathrm{~b}$ & $7.00 \mathrm{~b}$ & $16.30 \mathrm{~b}$ & $71.58 \mathrm{~b}$ \\
\hline 15 & $10.46 \mathrm{a}$ & $32.76 \mathrm{a}$ & $8.88 \mathrm{a}$ & $17.73 \mathrm{a}$ & $74.78 \mathrm{a}$ \\
\hline Tukey test P-value 0.05 & 1.24 & 1.95 & 1.12 & 1.17 & 1.37 \\
\hline \multicolumn{6}{|l|}{ Duration of Irrigation (hours) } \\
\hline 0.5 & $10.73 \mathrm{a}$ & $34.28 \mathrm{a}$ & $8.76 \mathrm{a}$ & $18.91 \mathrm{a}$ & $68.09 \mathrm{a}$ \\
\hline 1.0 & $10.52 \mathrm{a}$ & $34.32 \mathrm{a}$ & $8.66 \mathrm{a}$ & $16.53 \mathrm{~b}$ & $74.61 \mathrm{~b}$ \\
\hline 1.5 & $6.82 \mathrm{~b}$ & $24.51 \mathrm{~b}$ & $6.41 \mathrm{~b}$ & $15.62 \mathrm{~b}$ & $76.84 \mathrm{c}$ \\
\hline Tukey test P-value 0.05 & 1.91 & 2.10 & 1.71 & 1.80 & 2.12 \\
\hline Interaction between treatments & $(-)$ & $(-)$ & $(-)$ & $(-)$ & $(-)$ \\
\hline
\end{tabular}

Note: Numbers followed by the same letter in the column, and the same treatment are not significantly different based on the Tukey test P-value 0.05 . (-) there is no interaction between organic matter treatment and the duration of irrigation water supply. 
Organic fertilizers play a role in increasing crop yields because they contain complete nutrients, both macro, and micronutrients needed by plants. The application of 3,000 $\mathrm{kg} \cdot \mathrm{ha}^{-1}$ of organic fertilizer combined with $50 \mathrm{~kg} / \mathrm{ha}$ of biological fertilizer can give the highest yield of dried onion tubers $\left(23.22 \mathrm{~kg} .15 \mathrm{~m}^{-2}\right)$. It shows that the use of organic and natural fertilizers can increase nutrient content so that it can help the formation and enlargement of onion bulbs. Organic fertilizers can provide sufficient nutrition in the root area for the process of tuber formation. The application of organic fertilizer and charcoal increases nutrient reserves in the plant rooting zone, reducing nutrient leaching [25]. Manure is one of the organic fertilizers that are often used as fertilizer, one of which is goat manure [26].

Furthermore, the irrigation duration significantly affected the fresh weight of tubers per clump. The duration of a $0.5-$ hour water supply produced fresher tuber weight per clump. It was different from the treatment duration of 1.5 hours irrigation, but it was not significantly different from the water supply of 1.0 hour. It shows that to obtain high tuber yields required a certain amount of soil water content for optimal photosynthesis. A high photosynthesis rate will produce photosynthate to be supplied to the tubers as a more top sink. Soil moisture of $100 \%$ field capacity (FC) results in higher physiological activity in dry matter. On the other hand, 50\% FC and $150 \%$ FC moist soil reduces physiological activity and yields of 'Lembah Palu' shallot varieties at all heights [23].

\subsection{The yield of bulbs per hectare}

The yield of shallot bulbs is expressed in fresh tuber weight after harvest and showed in t.ha ${ }^{-1}$. There was no significant effect of interaction between the combination of irrigation water duration treatment and bokashi organic fertilizer on the number of tubers per hectare. Still, the treatment of irrigation water duration and the treatment of organic bokashi fertilizer each had a significant influence on the yield of tubers per hectare. The results of the Tukey test at P-value 0.05 (Table 3 ) indicate that the application of $15 \mathrm{t}^{-h^{-1}}$ bokashi organic fertilizer shows higher tuber yields per hectare $\left(8.88\right.$ t.ha $\left.^{-1}\right)$ and significantly different from without bokashi organic fertilizer (7.00 t.ha $\mathrm{t}^{-1}$. The application of manure and compost can help improve crop productivity and quality and maintain soil fertility [27]. In general, a combination of types and doses of organic fertilizer can produce growth and yields of onions that are higher than without organic fertilizer [1].

Water duration of irrigation significantly influences tuber yield per hectare. The duration of the 0.5 hour water supply yields the highest tuber yield per hectare $\left(8.76\right.$ t.ha $\left.^{-1}\right)$ and is significantly different from the 1.5 hour water supply, but not significantly different from the 1.0 hour water supply [28].

\subsection{Total soluble solids (TSS)}

There was no significant effect of interaction between the combination of irrigation water duration treatment and bokashi organic fertilizer to the total soluble solids (TSS) in the LPVoS tubers. Still, the treatment of irrigation duration and the use of bokashi organic fertilizer each gave a real influence on the TSS in the tuber. Tukey test at P-value 0.05 (Table 3) shows that the application of $15 \mathrm{t}^{-h^{-1}}$ bokashi organic fertilizer produces more soluble solids in the tuber (17.73 Brix) and is significantly different from without the use of organic bokashi fertilizer (16.30 Brix ). Organic matter can increase soil water content, so that water is available to plants in support of the physiological process for the formation of photosynthetic products in the form of carbohydrates. The organic fertilizer, however, enhanced the TSS in the onion bulb harvested [29]. Shallot plants will experience a severe water deficit in $50 \%$ of irrigation water needs, thus reducing plant growth and tuber yield and farmers' profits [30].

Furthermore, the treatment of irrigation duration significantly affected the TSS in the tuber, where the irrigation duration 0.5 hours produced the highest TSS in the tuber (18.91 Brix) and was significantly different from 1.0-hour water treatment and 1.5 hours. It can be caused by giving too long a water that can cause the water content in the tuber to be higher, to reduce the content of dissolved solids on the bulbs of the shallot. High availability of water for plants can negatively affect the soluble content and percentage of sugar reduction in fruit. Limited irrigation volume can lead to the development of small-sized fruit, lower yields, premature aging of plants, and higher susceptibility to various diseases [31]. TSS contents did not show any significant correlation with $\mathrm{K}$ level, but it increased with an increase in irrigation level [32]. The LP-VoS produces higher photosynthesis rates, tuber hardness, and total soluble solids at all water levels and altitudes [23]. Irrigation deficits applied to tomatoes appeared to have positive benefits on water use efficiency and improved tomato processing quality [33]. Non-structural carbohydrate composition of the bulb can limit the increase in osmotic potential by increasing TSS because it reduces the concentration and gradient of osmotic to the bulb [34].

\subsection{Tubers moisture content}

There was no significant effect of interaction between the combination of irrigation water duration treatment and bokashi organic fertilizer on the tuber water content of LP-VoS. Still, the treatment of irrigation duration and the use of bokashi organic fertilizer each had a significant influence on the water content of the tuber. Tukey test at P-value 0.05 (Table 3) shows that the application of $15 \mathrm{t}^{-h^{-1}} \mathrm{~b}^{-}$bokashi organic fertilizer produced higher tuber moisture content $(74.78 \%)$ and was significantly different from without organic fertilizer $(71.58 \%)$

It shows that the application of organic matter can increase water content in tubers because the role of organic matter can increase the ability of the soil to bind water, compared to soils that lack organic matter content. Furthermore, the treatment of irrigation duration significantly affected the water content in the tuber, where the period of water supply 1.5 hours produced the highest water content in the tuber $(76.84 \%)$, followed by the treatment of water supply 1.0 hour and 0.5 -hour water treatment showed the lowest water content in tubers $(68.09 \%)$. Likewise, giving water for a long time causes an increase in water content in the bulbs of shallot. The use of black silver plastic mulch needs to be applied to onion plants. Water is trapped under the mulch and suppresses the rate of evaporation so that the soil water content is higher. The result will affect the water content of the onion bulbs. Saving water with deficit irrigation for vegetable crops has become a real concern for maintaining crop yields and maintaining production quality [35].

\subsection{Circle of bulb}

The results of the analysis of variance showed that there was a significant interaction between the treatment of irrigation duration and the application of bokashi organic fertilizer to the 
LP-VoS circle of bulb. The results of the Tukey test at P-value 0.05 (Table 4) show that the combination of 0.5 hours of water supply with the addition of $15 \mathrm{t}^{-h^{-1}}$ organic fertilizer produced the most substantial circle of bulb $(6.40 \mathrm{~cm})$.

The smallest tuber girth is obtained in a combination of 1.5 hours of water supply with 15 t.ha $^{-1}$ organic fertilizer. It shows that by giving shorter water but followed by providing natural fertilizer bokashi, goat manure can increase the development and enlargement of the tuber. The role of organic bokashi fertilizer can provide the nutrients needed for plant growth and development. Soil goat manure can increase the availability of nutrients in the soil, the nutritional status of $\mathrm{N}, \mathrm{P}, \mathrm{K}, \mathrm{Ca}$, and $\mathrm{Mg}$ and organic matter for pepper growth and production [36]. From the physical aspect of the soil, organic matter can increase the ability of the soil to bind groundwater so that it is available for plant growth needs. Water is an essential component in the life of living things. Water often limits the growth and development of plants. Water requirements for plants vary, depending on the type of plant and its growth phase [21]. The LP-VoS has adapted well to dry land with a maximum water supply at a condition of $100 \%$ FC. The applied irrigation levels had substantial effects on the size i.e. diameter of onion bulbs [37]. Knowledge of soil water content in the field capacity or soil water pool is essential. This knowledge can be used to assess crop water requirements, irrigation scheduling, and predict crop responses to irrigation [20].

Table 4. Effect of a combination of organic matter treatment and irrigation duration on the circle of shallot bulbs

\begin{tabular}{cc}
\hline $\begin{array}{c}\text { The treatment combination of duration water } \\
\text { (hours) and bokashi fertilizer }\left(\mathbf{t . h a}^{-1}\right)\end{array}$ & $\begin{array}{c}\text { Circle of } \\
\text { bulb }(\mathbf{c m})\end{array}$ \\
\hline $0.5+0$ & $5.47 \mathrm{ab}$ \\
$0.5+15$ & $6.40 \mathrm{a}$ \\
$1.0+0$ & $5.01 \mathrm{~b}$ \\
$1.0+15$ & $5.61 \mathrm{ab}$ \\
$1.5+0$ & $5.51 \mathrm{ab}$ \\
$1.5+15$ & $4.65 \mathrm{~b}$ \\
Tukey test at P-value 0.05 & 0.97 \\
Interaction between treatments & $(+)$ \\
\hline
\end{tabular}

Note: The number followed by the same letter in the same column is not significantly different based on the Tukey test at P-value 0.05 . (+) there is an interaction between the treatment of organic matter and the duration of the irrigation.

\section{CONCLUSION}

Application of irrigation duration 0.5 - 1 hour and addition of organic fertilizer 15 t.ha- ${ }^{-1}$ could increase soil moisture so it can growth, yields, and quality of shallot bulb. For the cultivation of 'Lembah Palu' varieties of shallots in dry land, it is necessary to apply organic fertilizers to increase the soil water content for increased production and quality.

\section{ACKNOWLEDGMENT}

This research was conducted at the expense of the Directorate General of Higher Education, through a flagship Research scheme. For this reason, the authors express their thanks to the Ministry of Education of the Republic of Indonesia and the Tadulako University Research Institute for all the facilities provided so that this research can be carried out well.

\section{REFERENCES}

[1] Bahrudin, B., Ansar, M., Thaha, A.R. (2019). Organic fertilizers are effective in increasing growth and productivity of shallot Lembah Palu varieties. Agroland, 6(1): 13-19. https://doi.org/10.22487/j24077593.2019.v6.i1.12145

[2] Galagi, S.L., Aiyen, A., Pasigai, M.A. (2017). Growth and yield of onion (Allium ascalonicum L.) against various concentrations of liquid organic fertilizers. Agroland, 4(1): 26-34. https://doi.org/10.22487/j24077593.2017.v4.i1.9407

[3] Ji, R., Dong, G., Shi, W., Min, J. (2017). Effects of liquid organic fertilizers on plant growth and rhizosphere soil characteristics of chrysanthemum. Sustainability, 9(5): 841. https://doi.org/10.3390/su9050841

[4] Sumbayak, R.D.L., Susila, A.D. (2018). Spray hose irrigation system increased yield of polyethylene mulched shallot. Journal of Tropical Crop Science, 5(2): 49-54. https://doi.org/10.29244/jtcs.5.2.49-54

[5] Ahmadi, S.H., Agharezaee, M., Kamgar-Haghighi, A.A., Sepaskhah, A.R. (2017). Comparing canopy temperature and leaf water potential as irrigation scheduling criteria of potato in water-saving irrigation strategies. International Journal of Plant Production, 11(2): 333-348. https://doi.org/10.22069/ijpp.2017.3428

[6] Temesgen, T., Ayana, M., Bedadi, B. (2018). Evaluating the effects of deficit irrigation on yield and water productivity of furrow irrigated onion (Allium cepa L.) in Ambo, Western Ethiopia. Irrigation \& Drainage Systems Engineering, 7(1): 1-6. https://doi.org/10.4172/21689768.1000203

[7] Zheng, J.H., Huang, G.H., Wang, J., Huang, Q.Z., Pereira, L.S., Xu, X., Liu, H.J. (2012). Effects of water deficits on growth, yield and water productivity of dripirrigated onion (Allium cepa L.) in an arid region of Northwest China. Irrigation Science, 31: 995-1008. https://doi.org/10.1007/s00271-012-0378-5

[8] Haynes, R.J., Naidu, R. (1998). Influence of lime, fertilizer and manure applications on soil organic matter content and soil physical conditions: A review. Nutrient Cycling in Agroecosystems, 51: 123-137. https://doi.org/10.1023/A:1009738307837

[9] Ansar, M., Fathurrahman. (2018). Sustainable integrated farming system: A solution for national food security and sovereignty. IOP Conference Series: Earth and Environmental Science, 1st International Conference on Food Security and Sustainable Agriculture in The Tropics (IC-FSSAT) 24-25 October 2017, Sulawesi Selatan, Indonesia, vol. 157. https://doi.org/10.1088/1755-1315/157/1/012061

[10] Kusuma, M.E. (2012). Pengaruh beberapa jenis pupuk kandang terhadap kualitas bokashi. Jurnal Ilmu Hewani Tropika, 1(2): 41-46.

[11] Irshad, M., Eneji, A.E. Hussain, Z., Ashraf, M. (2013). Chemical characterization of fresh and composted livestock manures. Journal of Soil Science and Plant Nutrition, 13(1): 115-121. https://doi.org/10.4067/s0718-95162013005000011

[12] Badgley, C., Moghtader, J., Quintero, E., Zakem, E., Chappell, J.M., Avilés-Vázquez, K., Samulon, A., Perfecto, I. (2007). Organic agriculture and the global food supply. Renewable Agriculture and Food Systems, 22(2):

86-108. 
https://doi.org/10.1017/S1742170507001640

[13] Azmi, C., Hidayat, I.M., Wiguna, G. (2016). Pengaruh varietas dan ukuran umbi terhadap produktivitas bawang merah. Journal of Horticulture, 21(3): 206-213. https://doi.org/10.21082/jhort.v21n3.2011.p206-213

[14] Paiman. (2015). Perancangan percobaan untuk pertanian (experimental design for agriculture). 1st ed, Yogyakarta, Indonesia: UPY Press.

[15] Rawls, W.J., Pachepsky, Y.A., Ritchie, J.C., Sobecki, T.M., Bloodworth, H. (2003). Effect of soil organic carbon on soil water retention. Geoderma, 116(1-2): 6176. https://doi.org/10.1016/S0016-7061(03)00094-6

[16] Marinari, S., Masciandaro, G., Ceccanti, B., Grego, S. (2000). Influence of organic and mineral fertilisers on soil biological and physical properties. Bioresource Technology, 72(1): 9-17. https://doi.org/10.1016/S09608524(99)00094-2

[17] Noorhadi, Sudadi. (2003). Kajian pemberian air dan mulsa terhadap iklim mikro pada tanaman cabai di tanah entisol. Jurnal Ilmu Tanah dan Lingkungan 2003, IV(1).

[18] Firmansyah, I., Liferdi, L., Khaririyatun, N., Yufdi, M.P. (2015). Pertumbuhan dan hasil bawang merah dengan apaliksi pupuk organik \& pupuk hayati pada tanah alluvial. Journal of Horticulture, 25(2): 133-141. https://doi.org/10.21082/jhort.v25n2.2015.p133-141

[19] Rastiyanto, E., Sutirman, Pullaila, A. (2013). Pengaruh pemberian pupuk organik kotoran kambing terhadap pertumbuhan dan hasil tanaman kailan (Brassica Oleraceae L.). Bul. Ikat., 3(2): 36-40.

[20] Paiman, Effendy, I. (2020). The effect of soil water content and biochar on rice cultivation in polybag. Open Agric., 5(1): 117-125. https://doi.org/10.1515/opag2020-0012

[21] Felania, C. (2017). Pengaruh ketersedian air terhadap pertumbuhan kacang hijau (Phaceolus radiatus). Prosiding Seminar Nasional Pendidikan Biologi dan Biologi Jurusan Pendidikan Biologi, Fakultas MIPA, Universitas Negeri Yogyakarta 2017, 131-138.

[22] Suhartono, Zaed, S., Khoiruddin, A. (2008). Pengaruh interval pemberian air terhadap pertumbuhan dan hasil tanaman kedelai (Glicine max (L.) Merril) pada berbagai jenis tanah. Embryo, 5(1): 98-112.

[23] Anshar, M., Tohari, T., Sunarminto, B.H., Sulistyaningsih, E. (2013). Tanggap fisiologi dan hasil bawang merah (Allium cepa L. kelompok aggregatum) terhadap lengas tanah dan ketinggian tempat berbeda. Biota, 18(1): 1-10 https://doi.org/10.24002/biota.v18i1.258

[24] Tri Hapsari, R., Mejaya, I.M.J. (2016). Pengaruh frekuensi pemberian air terhadap pertumbuhan dan hasil ubi jalar. Prosiding Seminar Nasional II Tahun 2016, Kerjasama Prodi Pendidikan Biologi FKIP dengan Pusat Studi Lingkungan dan Kependudukan (PSLK) Universitas Muhammadiyah Malang Malang, 748-754.

[25] Steiner, C., Teixeira, W.G., Lehmann, J., Nehls, T., de Macêdo, J.L.V., Blum, W.E.H., Zech, W. (2007). Long term effects of manure, charcoal and mineral fertilization on crop production and fertility on a highly weathered Central Amazonian upland soil. Plant and Soil, 291: 275290. https://doi.org/10.1007/s11104-007-9193-9

[26] Noviyanty, A., Salingkat, C.A. (2019). The effect of application of rice dishwater and manure as organic of fertilizers to the growth of mustrad (Brassica juncea L.).
AGROLAND The Agricultural Sciences Journal (eJournal), 5(2): 74-82. https://doi.org/10.22487/j24077593.2018.v5.i2.11974

[27] Anwar, M., Patra, D.D., Chand, S., Alpesh, K., Naqvi, A.A., Khanuja, S.P.S. (2005). Effect of organic manures and inorganic fertilizer on growth, herb and oil yield, nutrient accumulation, and oil quality of French basil. Communications in Soil Science and Plant Analysis, 36(13-14): 1737-1746. https://doi.org/10.1081/CSS200062434

[28] Sadras, V.O. (2004). Yield and water-use efficiency of water- and nitrogen-stressed wheat crops increase with degree of co-limitation. in European Journal of Agronomy, 21(4): 455-464. https://doi.org/10.1016/j.eja.2004.07.007

[29] Lee, J. (2010). Effect of application methods of organic fertilizer on growth, soil chemical properties and microbial densities in organic bulb onion production. Scientia Horticulturae, 124(3): 299-305. https://doi.org/10.1016/j.scienta.2010.01.004

[30] Abdelkhalik, A., Pascual-Seva, N., Nájera, I., Domene, M.A., Baixauli, C., Pascual, B. (2019). Effect of deficit irrigation on the productive response of drip-irrigated onion (Allium cepa L.) in Mediterranean conditions. The Horticulture Journal, 88(4): 1-12. https://doi.org/10.2503/hortj.UTD-081

[31] Hanson, B.R., May, D.M., Schwankl, L.J. (2003). Effect of irrigation frequency on subsurface drip irrigated vegetables. Hort. Technology, 13(1): 115-120. https://doi.org/10.21273/horttech.13.1.0115

[32] Kaur, A., Kaur, B., Sraw, P.K., Singh, K. (2017). Response of onion to applied potassium at farmer's scale field. International Journal of Current Microbiology and Applied Sciences (IJCMAS), 6(7): 2491-2496. https://doi.org/10.20546/ijcmas.2017.607.353

[33] Favati, F., Lovelli, S., Galgano, F., Miccolis, V., Di Tommaso, T., Candido, V. (2009). Processing tomato quality as affected by irrigation scheduling. Scientia Horticulturae, 122(4): 562-571. https://doi.org/10.1016/j.scienta.2009.06.026

[34] Sinclair, P.J., Blakeney, A.B., Barlow, E.W.R. (1995). Relationships between bulb dry matter content, soluble solids concentration and non-structural carbohydrate composition in the onion (Allium cepa). Journal of the Science of Food and Agriculture, 69(2): 203-309. https://doi.org/10.1002/jsfa.2740690210

[35] Wakchaure, G.C., Minhas, P.S., Meena, K.K., Singh, N.P., Hegade, P.M., Sorty, A.M. (018). Growth, bulb yield, water productivity and quality of onion (Allium сера L.) as affected by deficit irrigation regimes and exogenous application of plant bio-regulators. Agricultural Water Management, 199: 1-10. https://doi.org/10.1016/j.agwat.2017.11.026

[36] Awodun, M.A., Omonijo, L.I., Ojeniyi, S.O. (2007). Effect of goat dung and NPK fertilizer on soil and leaf nutrient content, growth and yield of pepper. International Journal of Soil Science, 2(2): 142-147. https://doi.org/10.3923/ijss.2007.142.147

[37] Sharma, A., Panja, P., Mandal, J. (2017). Effect of intregated nutrient management on onion (Allium cepa $\mathrm{L}$.) yield, quality attributes, soil properties and production economics under field condition. Indian Journal of Ecology, 44(5): 355-359. 